\title{
SEDIMENTATION IN DUNE FORESTS, MANGROVE FORESTS AND CC BLOCK SYSTEM AND ASSOCIATED TOPOGRAPHIC CHANGES
}

\author{
ASHABUL HOQUE ${ }^{1}$, DIPANKAR KUMAR ${ }^{2}$, ANIP KUMAR PAUL ${ }^{3}$, MASUDAR RAHMAN ${ }^{4}$, \\ GOUR CHANDRA PAUL ${ }^{1}$ AND SHIN-ICHI AOKI ${ }^{5}$
}

Department of Mathematics, University of Rajshahi, Rajshahi-6205, Bangladesh

\begin{abstract}
This paper is concerned with the deposition of sediment due to dune forests (Nakatajima dune, Japan) and CC block system on a riverbank (Padma, Bangladesh). Measurements of sediment deposition were carried out at Nakatajima dune, Japan and at Padma riverbank, Rajshahi, Bangladesh using Global Positioning System (GPS). $2442 \mathrm{~m}^{3}$ sediment migrates each year to the East side of Nakatajima dune by wind and the edge of the dune develops about 6-7 m/year due to the existence of forests. Sedimentation rate is also greater in shallower mangrove areas. The trapped sediment height varies from 8.0 to $10.0 \mathrm{~cm}$ in the mangrove-lined bank. Mangrove forests help to trap $25 \%$ more sedimentation at low tide than at high tide. On the other hand, only for setting up the $\mathrm{CC}$ block and groynes along the bank, the sedimentation rate is observed almost twice than that of the previous year. An analysis shows that there is a similarity of sedimentation among dune, beach forests, mangrove forests and CC blocks.
\end{abstract}

Keywords: mangrove forest, dune, sedimentation, storm surge, sea-level rise

\section{INTRODUCTION}

Wave transformation in shallow water and its related problems, such as, beach and dune erosion and mitigating measures are the most important topics with which coastal engineers have been deeply concerned for a long time. Coastal and dunes provide extensive protection to many of the world's shorelines. The beach and dune zone of the coast are heavily attacked by the incoming wave, usually resulting in erosion processes. Besides the factors, dune forests have also been considered as one of the key adaptations and mitigation-measure factors against extreme events, such as, storm surges, tsunami etc. They are generally known to favour of deposition and it is scientifically proved (Santen et al. (2007), Junaidi and Aoki (2009), Adame et al. (2010)). For the formation of dune, a source of sand is required. Usually sand is carried out from the beach by onshore winds, which in turn is trapped by vegetation and is stabilized. The exact nature of the response of coastal dune forests to the projected rise in sea level is still largely a matter of speculation and probably adjacent dune forest systems will react in two different ways: sand-fixing and sandbuilding.

Mangroves efficiently trap and stabilize sediment (Fig. 1(a)) and reduce the risk of shoreline erosion because they dissipate wave energy. Harada et al. (2002) conducted a hydraulic experiment to study the tsunami reduction effect of the coastal permeable structures using five different modelsmangroves, coastal forest, wave dissipating block, breakwater rock, and houses. This work reveals that mangroves are effective as compared to concrete seawall structures for reduction of tsunami-hit house damages behind the forest.

Corresponding author: <ashabulh@yahoo.com>.

${ }^{2}$ Department of Mathematics, Bangabandhu Sheikh Mujibur Rahman Science and Technology

University, Gopalgonj

${ }^{3}$ Department of Mathematics, University of Rajshahi, Rajshahi-6205, Bangladesh

${ }^{4}$ Department of Mathematics, Bangladesh Army University of Engineering and Technology

(BAUET), Bangladesh

${ }^{5}$ Dept. of Civil Engineering, Graduate School of Engineering, Osaka University, 2-1Yamadaoka, Suita, Osaka 565-0871, Japan 
Most of the studies have dealt with the relationship between forest vegetation and their wave attenuation performance. But the research dedicated to the relationship between sedimentation and wave attenuation is not found yet. Cowell et al. (2006) suggested that sediment budget approaches are most useful to assess beach response to climate change. Although Carter (1991) and Junaidi and Aoki (2009) discussed the importance of dune forests and vegetation for stabilizing the sediment (Fig. 1(b)). So far, research dedicated to sedimentation induced by coastal forests during coastal flooding is fairly limited and the relationship of sedimentation between coastal forests and dune forests is not documented yet.

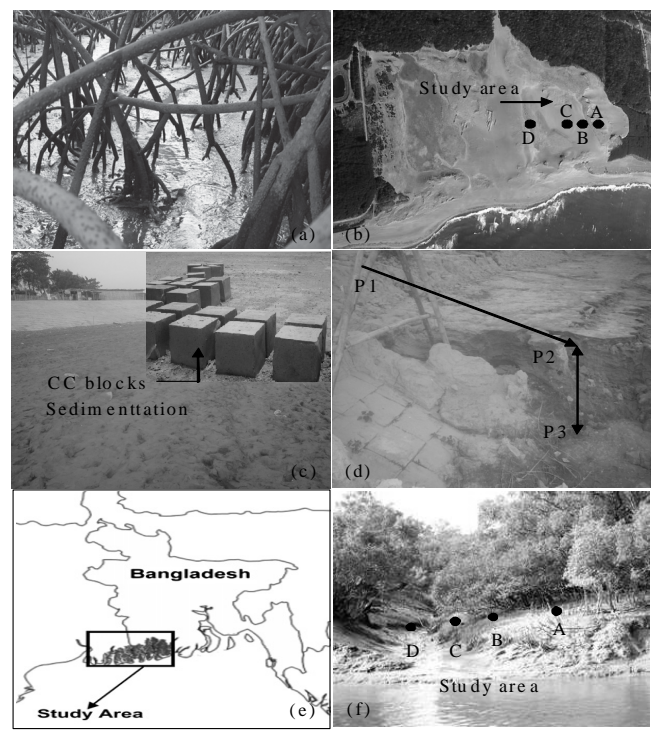

Fig. 1. (a) Complex root systems of mangrove; (b) Nakatajima dune, Japan: Legend: A-C mangrove-lined bank data and D non-mangrove bank data with geo-coordinates position (34.660858, 137.743175), (c) concrete CC blocks at river bank of Padma, Rajshahi in position (24.358980, 88.621194), (d) sediment sampling points, Rajshahi in position (24.359032, 88.620796), (e) Sundarban, study area and (f) sediment elevation in mangrovelined bank and non-mangrove bank in position (21.944875, 89.585744). Legend: A-C mangrove-lined bank data and D non-mangrove bank data.
On the other hand, protection of the riverbank along the major rivers of Bangladesh has always been considered as a challenging engineering task against the nature and Bangladesh Water Development Board (BWDB) has been practicing different technology for controlling river bank erosion with the purpose of protecting lives and livelihoods. The impact of identification and evaluation was carried out comparing the protective works using geobags with $\mathrm{CC}$ block and protective works without geobags (Wahed et al. (2011), BWDB (2008) and NHC (2006). They found that launching performance of sand filled geobags is better than CC blocks.

The aim of the paper is studying (i) sedimentation processes in the river sides, (ii) mangrove forests during the extreme flood events and (iii) sedimentation process in the dune forests.

\section{Various aspects of coastal mangroves}

\section{Dune stabilization}

Coastal dune vegetation is the plants that grow on beaches and sand dunes form communities. Dune vegetation is highly adapted to the salt laden winds of the coast, and maintains the fore dunes by holding the sand already in the dune, trapping sand blown up from the beach, and aiding in the repair of damage inflicted on the dune either by natural phenomena or by human impact. The combination of dune height, dune shape and intact vegetation creates a protective system which directs salt-laden winds upwards and over the dune crest (Fig. 1b). Dune vegetation not only stabilizes the dune, but also has habitat, educational and recreational values. The beach and the fore dune are used extensively for active and passive recreation. 
Vegetation contributes to recreational and aesthetic values. Indirectly, the stabilizing ability of vegetation limits the amount of wind blown sand in the beach environment and thus enhances its recreational utility. Similarly, healthy vegetation significantly contributes to beach user comfort by reducing reflected radiation from the fore dune. In the absence of dune vegetation, sand moves towards inland from the beach and coastal recession takes place.

\section{Adaptation to change in sea-level}

As ocean temperature increases due to climate change, thermal expansion will cause the density to decrease and so increase the volume of ocean waters, raising sea level. IPCC's estimation of global sea level rise was 1.0 to $2.0 \mathrm{~mm} /$ year over the last century. Nicholls et al. (1999) estimated that by the 2080s, sea-level rise could

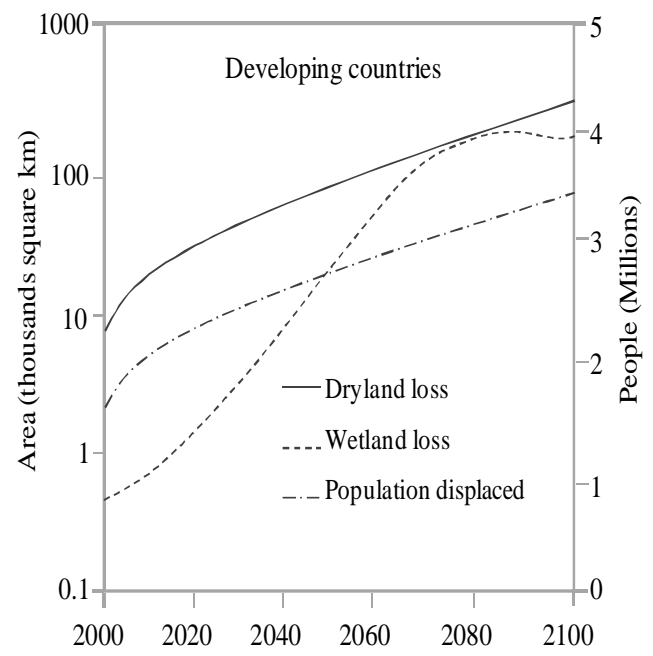

(a) Developing countries cause the loss of up to $22 \%$ of the world's coastal wetlands. As sea level continues to rise, more low-lying coastal regions in developing countries will be affected by coastal flooding and coastline erosion. Fig. 2 shows the consequences of a rise in sea level for developing (Fig. 2a) and developed countries (Fig. 2b). The consequences of sea-level rise will be far greater for developing countries than for developed countries. In the absence of a substantially improved protection, coastal flooding could grow tenfold or more by the 2080s, to affect more than 100 million people/yr, due to sea-level rise alone (Fig. 2a). As a developing country, Bangladesh is too poor to be able to adapt to such a rise in sea level. In fact, many of the nations that are most vulnerable to sea-level rise do not have the resources for the necessary adaptation.

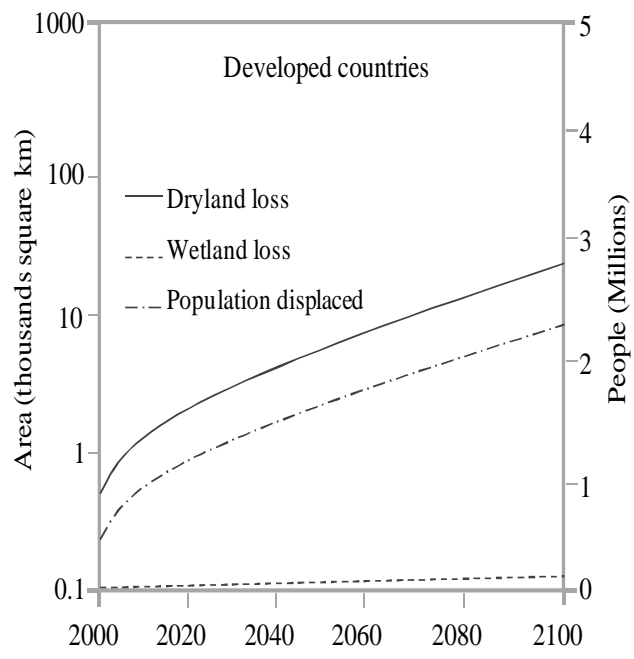

(b) Developed countries

Fig. 2. The effects of an assumed sea-level rise for (a) developing and (b) developed countries (modified IPCC, 2007). 
Many mangrove forests are being exploited and some are being destroyed, reducing resilience to accommodate future sea-level rise. Bangladesh is highly vulnerable to sea level rise, as it is a densely populated coastal country. World Bank (2000) showed $10.0 \mathrm{~cm}, 25.0 \mathrm{~cm}$ and $1.0 \mathrm{~m}$ rise in sea level by 2020, 2050 and 2100; affecting $2 \%, 4 \%$ and $17.5 \%$ of total land mass respectively in Bangladesh. It is also observed from literature that $50 \%$ of mangrove has been lost in the past 35 years; yet with greatly increased sediment supply to the coastal zone in some places, mangrove colonization has expanded seaward in suitable habitats.

Ellison (1993) and Parkinson et al. (1994) suggest that mangrove accretion in low and high-island settings with low sediment supply may not be able to keep up with future sea-level rise, whereas Snedaker et al. (1994) suggests that low-island mangroves may be able to accommodate much higher rates of sea-level rise. In some protected coastal settings, inundation of low-lying coastal land may promote progressive expansion of mangroves with sea-level rise (Richmond et al., 1997). The ability of mangroves to successfully adapt to change in sea-level, as already noted, depends on the accretion rate relative to rate of sea-level change (Fig. 3).

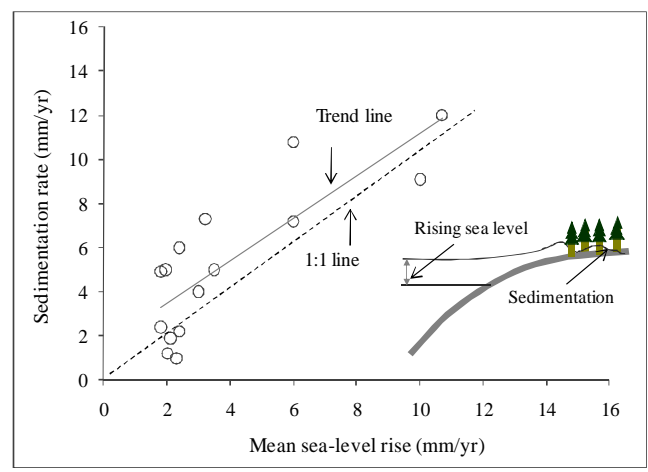

Fig. 3. Relationship between sedimentation rates in mangrove forests and mean sea-level rise (after, Alongi 2008).
The data are insufficient to perform a more detailed analysis, but plot of a number of empirical measurements of accretion rate vs regional mean sea-level rise, indicates that the average sedimentation rates somewhat greater than the rate of mean sea-level rise (Alongi 2008). Ellison (1993) showed that when the sedimentation rates under mangroves did not keep up with sea-level rise rates, old mangroves drowned and new mangrove forests colonized higher elevations.

\section{Removal of $\mathrm{CO}_{2}$}

Mangroves are known to store carbon and reduce carbon dioxide $\left(\mathrm{CO}_{2}\right)$ concentration in the atmosphere. This perhaps reduces the problems that go with the 'green house gases' and global warming. The mangroves are capable of accumulating and storing carbon in the soil in large amount. For example, a Rhizophora forest can divert a remarkably high amount of carbon below ground. The young trees initially draw in carbon at a faster rate, older forests can play a more significant role because they store far more carbon than young forests. In his study, estimated that a loss of about $35 \%$ of the world's mangroves has resulted in a net loss of $3.8 \mathrm{x}$ $10^{14} \mathrm{~g} \mathrm{C}$ stored as mangrove biomass (Cebrain 2002). According to Fujimoto (2000), a 20-year old plantation of mangroves stores $11.6 \mathrm{~kg} \mathrm{~m}^{-2}$ of carbon with $\mathrm{C}$ burial rate of about $580 \mathrm{~g} \mathrm{~m}^{-2} \mathrm{yr}^{-1}$.

On the other hand, plantation of mangroves can provide great benefits to control global climate change as they stabilize atmospheric carbon. Mukhopadhyay et al. (2000) estimated gas (Carbon dioxide) exchange from the atmosphere by the forest and aquatic ecosystem of the Sundarban mangrove in Bangladesh at a rate of 24 x 109 and 16 x $106 \mathrm{~kg} \mathrm{C}$ year $^{-1}$, respectively. 
According to Farnsworth et al. (1996), Rhizophora mangle under high $\mathrm{CO}_{2}$ conditions which was double than normal for one year, showed greater accumulation of biomass. Thus, in the case of high $\mathrm{CO}_{2}$, mangroves also respond well. The reason behind the fact is that the mangroves fix and store significant amounts of carbon and hence their loss may have impact on global carbon budget. The 2007 IPCC assessment has predicted that atmospheric $\mathrm{CO}_{2}$ concentrations will increase by 1.6-1.9\% $\mathrm{yr}^{-1}$ during this century. Wibisono et al. (2011) measured the total $1,139,370$ ton $\mathrm{CO}_{2}$ from mangrove forests in Pasang Kayu area (Indonesia) based on GIS analysis. They also observed that the dense mangrove forest stored large amount of $\mathrm{CO}_{2}$ compared to sparse mangrove forest. This information shows that the existence of mangrove forest is very important as $\mathrm{CO}_{2}$ reservoirs.

Protection of lives

Mangrove forests protect all types of coastal communities from the ferocity of cyclones and storms. An assessment was undertaken on loss of human lives and wealth after the tsunami

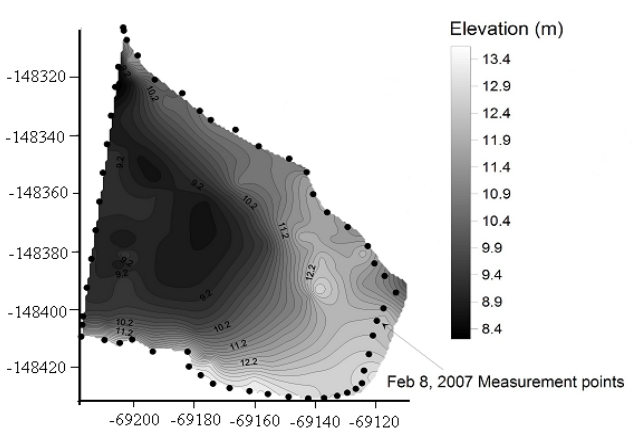

4 (a)
2004 in 18 coastal villages along with coastal vegetation and human inhabitation characteristics by Kathiresan and Rajendran (2005). They observed that the human deaths were low in the villages those are situated behind the mangrove forests, located at a distance ranging from 1 to $2.5 \mathrm{~km}$ away from the shoreline and also are in elevated places with steep topography. Similarly, it was observed that the dense growth of mangroves in Sundarbans saved Bangladesh from the killer impact of cyclone Sidr 2007. Data were collected by JSCE (2008) after Sidr 2007 near the world largest mangroves 'Sundarbans'.

The dead, missing, and the injured person of the personal suffering in 2007 were more greatly less than that of 1991. It was thought that the "Sundarbans" mangrove played vital role for diverting the route of the Sidr. On the basis of the 1991 storm surge and the cyclone Sidr of 2007, Bangladesh Government has taken a massive project of mangrove plantations in the coastal areas to reduce the impact of storm surges (Saenger and Siddiqi (1993), JSCE (2008)).

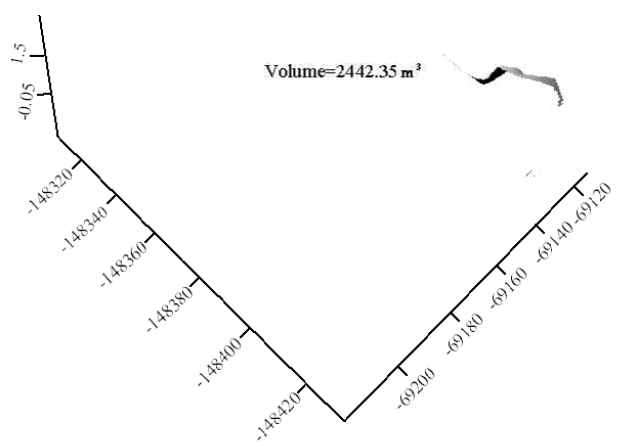

4 (b)

Fig. 4. (a) Digital elevation model of the monitored area in the East side (surveyed on Jan 28, 2008) and (b) 3D view of the new sand transport into study area (Nakatajima dune). 


\section{MATERIAL AND METHODS}

Nakatajima dune, Japan

The Nakatajima dune is approximately $1.0 \mathrm{~km}$ in length (from West to East) and $0.6 \mathrm{~km}$ in width, located near Magome River mouth along the Enshu-Nada coast, Hamamatsu city of Japan (Fig. 1(b)). Detailed surveys of the dune were done with randomly space measurements in flat smooth topography every two weeks in autumn to winter and once a month in spring to summer for two years (2007-2008). In each survey, sediment deposition and transportation due to wind were measured by Junaidi and Aoki (2009). The data collection technique and analysis are presented in Junaidi and Aoki (2009), so, they have not been included here. In order to know the topographic changes of Nakatajima dune by coastal forests, further analysis of these data are needed.

Fig. 4(a) shows the measurement points along the edge of Eastern end of the dune where sediment can be found to be migrated from West side to East side by wind. In order to calculate the change of cumulative volume of two years 2007 and 2008, the volume command Surfer 8 was used. The edge data of 2008 from full topographic shape was superimposed on the edge data of 2007. Finally, the topographic shape has been subtracte from 2008 to that of 2007 and calculated the cumulative volume which is plotted in Fig. 4(b).

Practically, it is observed that there is a sediment bar at the border line of forests. The ability of wind to carry sediments decreases as the velocity is slowed down by the dune forests to settling of sediment. In this analysis, the sampling points A, B, C were fixed with a distance $4.0 \mathrm{~m}$ at the dune forests zones and $\mathrm{D}$ was fixed with $50.0 \mathrm{~m}$ far from dune vegetation area (Fig. 1(b)).
Sundarban mangroves, Bangladesh

The location of study area includes Sundarban mangroves, the southern part of Bangladesh. In Fig. 1(f), points $A$ to $D$ show the sampling points for ground soil. The sampling points $\mathrm{A}$, $\mathrm{B}, \mathrm{C}$ were fixed with a distance of $6.0 \mathrm{~m}$ at the mangrove forests zone and D was fixed with $30.0 \mathrm{~m}$ far from mangrove forests area. The sediment column height ranged from 8.0 to 10.0 $\mathrm{cm}$ in the mangrove-lined bank and it varied 1.0 to $2.0 \mathrm{~cm}$ in the non-mangrove bank (Fig. 7(a)). This indicated that the change in sedimentation is greater in shallower mangrove areas than the non-mangrove bank. The sampling points $\mathrm{A}, \mathrm{B}$, $\mathrm{C}$ were set up on the same boarder line in front of North part of forests. Similar study was also conducted by Katherisan (2003) in Vellar estuarine mangrove where the sampling points were fixed with a distance of $5.0 \mathrm{~m}$ at the coastal forest vegetation zones (A, B, C). They estimated that mangroves help in trapping the sediment about $25 \%$ more at low tide than at high tide.

\section{River bank, Padma}

The river discharge during river flooding in Bangladesh is heavily laden with sediments, both suspended and bed-load, giving rise to a highly dynamic estuary. Flooding, floodplain sedimentation and bank erosion of these rivers influence life and livelihood of several millions of people. These rivers are very dynamic in nature as most part of Bangladesh has been formed by recent sediments and rivers that are loaded with huge sediment. As a result, rivers become very sensitive to changes in parameters like flood flow, sediment load and base level etc.

Bank erosion are observed from Talaimary to Shampur $(5.0 \mathrm{~km})$ which was threatening to the city dwellers of Rajshahi district. Bank erosion 
depends on many factors like (i) Non-cohesive loose sediment at the bank, (ii) Navigability reduction, (iii) Huge sediment volume, (iv) Formation giant channel with the main channel, (v) Amount of rainfall, (vi) Morphology of the river, (vii) Higher flow velocity, (viii) Barrier to natural flow etc (Uddin et at 2016). The erosion was suspected to be caused by higher flow velocity in monsoon season. The monsoon discharge in the Ganges in Bangladesh has increased while in the dry season it is decreased. So the government has constructed the concrete river embankment using CC blocks and GO textile under the supervision of Bangladesh Water Development Board (BWDB), Rajshahi (Fig. 1(c)). Fig. 1(c) shows that after monsoon season the significant sediment and clay are deposited and no further erosion is observed.

Field surveys were carried out along the river embankment of Padma, Rajshahi Bangladesh to investigate the performance of newly established CC blocks in reducing the bank erosion. Fig. 1(d) shows the arrangement of field test area at Talaimari, Rajshahi. In Fig. 1(d), P1 to P3 represent the sampling points for ground soil. A large hole was observed on the $\mathrm{CC}$ blocks near the sampling point $\mathrm{P} 2$ which imply that 2.0 $\mathrm{m}$ deep sediment deposition. The photograph was taken after two months of the monsoon season of 2010. The area was filled with earth clay.

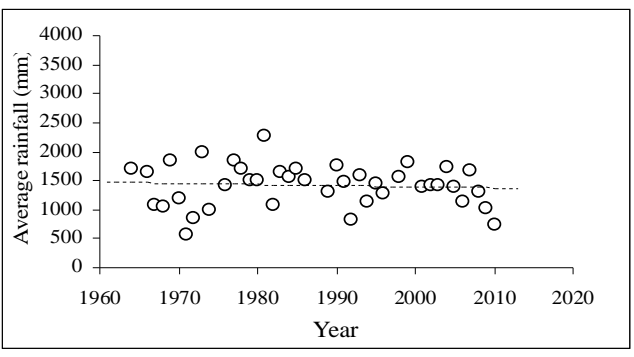

(a)

\section{RESULTS AND DISCUSSION}

Sedimentation due to CC blocks (riverside) and dune forests

Sedimentation on the river bed and river banks depends mainly on the river flow dynamics, morphology and sediment load. It has less effect on the CC blocks laid on the river side (Uddin et al. 2016). At Rajshahi there are groynes just above the study area (upstream). Those groynes are obstructing the flows of sediment laid water and as result sedimentation is going on the bank side.

Fig. 5(b) shows the comparison of sediment deposition and water discharge during the last three years 2008-2010. The annual peak and annual mean discharge data (2008-2010) for the Padma River at Hardinge Bridge were obtained from Water Development Board. A significant decreasing trend is observed in the annual peak water discharge (Fig. 5(b)). According to Webster et al. (2010), Farakka Barrage is responsible for the recent decrease in Ganges flooding and water discharge. Although water supply through the Padma has been reduced substantially in the year 2008, 2009 and 2010, where annual peak discharges were 54000, 40000 and $30000 \mathrm{~m}^{3} \mathrm{~s}^{-1}$ respectively, but siltation on the river-bed has been increased significantly (Fig. 5(b)).

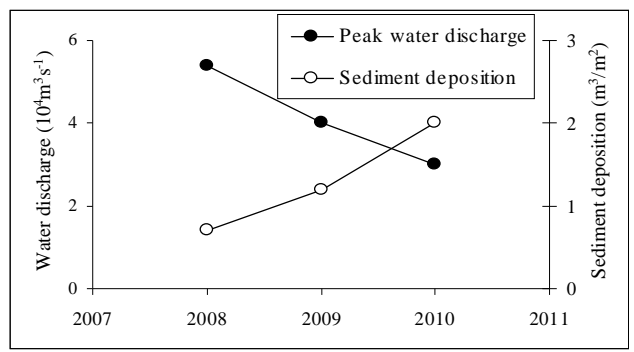

(b)

Fig. 5. (a) Annual average rainfall over Rajshahi and (b) Annual peak discharge of the Padma at Hardinge Bridge and sediment deposition at river -bank, Rajshahi. 
Taaouati et al. (2011) found the similar relationship between wave energy variation and sediment deposition. They showed that an increase in wave energy leads to a loss of sediment stock whereas a weak energy level permits to gain considerable quantities of sediment. It can be shown from Fig. 6(a) that the increased earth clay (sedimentation) due to $\mathrm{CC}$ blocks is improving slope stability and better river embankment in every year. After setup the CC blocks on the riverbank in 2008, the sedimentation rate is observed almost twice than that of the previous year. More field measurement campaigns in various conditions such as different CC block types and various topographies should be carried out. Fig. 6(b) shows the cumulative volume of sediment which is transmitted to eastern side by wind of Nakatajima dune in January, March, June and November of the year 2008. It can be observed from the Fig. 6(b) that the larger amount of sediment is transmitted in June and November, which may be due to higher wind speed. The wind velocity and direction were measured with propeller type anemometer at $10 \mathrm{~min}$ intervals. The maximum and average velocities for this period were $19.1 \mathrm{~ms}^{-1}$ and $3.6 \mathrm{~ms}^{-1}$ respectively. The average volume of migrated sediment was calculated about $2450 \mathrm{~m}^{3} /$ year from the study area in 2008.

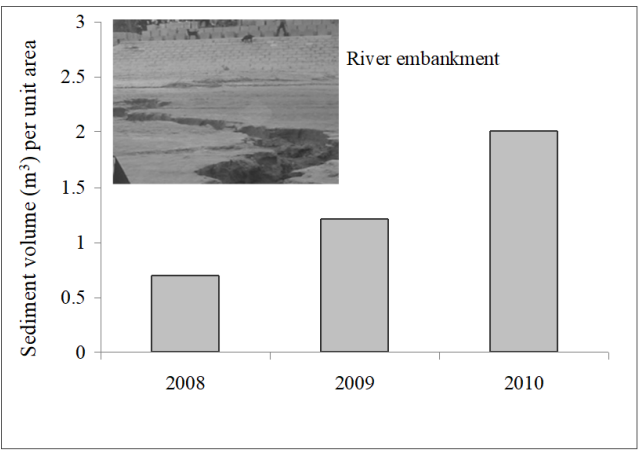

(a)

\section{Rainfall and Siltation cause of flood}

The rainfall pattern in Rajshahi is uni-modal with $70 \%$ of the annual rainfall occurring between June and September. According to Clemett et al. (2006), the average monthly rainfall data from the Rajshahi rainfall monitoring station shows that some monthly variation between years but clearly shows that November to March are months of very low rainfall. In Fig. 5(a), the annual average rainfall showed a decreasing trend over Rajshahi region by $3.0698 \mathrm{~mm} /$ year.

The flood of Rajshahi is generally marked with moderate rainfall and due to siltation of the Padma River. During the annual monsoon season, the rivers of Bangladesh flow at about $140,000 \mathrm{~m}^{3} \mathrm{~s}$, but during the dry season it reduces to 7,000 $\mathrm{m}^{3} \mathrm{~s}$. Among them, the flow of $35000 \mathrm{~m}^{3} \mathrm{~s}$ shares the Padma River. The data of climatic element such as rainfall ( $\mathrm{mm}$ ) that plays vital role for floods at Rajshahi for the period of January 1961 to December 2010 (i.e. 50 years) were used in this study.

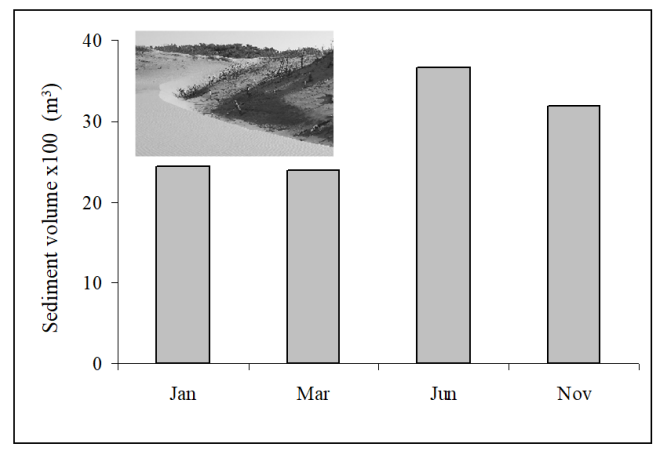

(b)

Fig. 6. Volume of sediment deposition in the study area: (a) river bank, Padma and (b) coastal dune, Nakatajima. 
Sedimentation in estuarine mangrove and dune forests

In Fig. (7), comparison of the sediment deposition data between estuarine mangrove system and dune vegetation has been done. Fig. 7(a) shows sedimentation by complex root system in the Sundarban mangrove forests. The higher sedimentation is observed within a mangrove-lined bank $(\mathrm{A}, \mathrm{B}, \mathrm{C})$ than without forest vegetation (D). On the other hand, Fig. 7(b) shows sediment elevation due to dune forests in Nakatajima dune. It is also observed that sediment elevation due to wind is larger within a mangrove-lined bank $(\mathrm{A}, \mathrm{B}, \mathrm{C})$ than without forest vegetation (D). The sediment elevation near the dune forest-lined bank ranged from 6.0 to $8.0 \mathrm{~m}$ while for the banks without forests it varied only from 1.0 to $2.0 \mathrm{~m}$. Katherisan (2003) measured higher concentration of suspended particles inside the forest-lined bank ranged from 0.09 to $0.15 \mathrm{~g} / \mathrm{L}$ while for the banks without forests it varied only from 0.008 to $0.01 \mathrm{~g} / \mathrm{L}$. He also estimated that mangroves help in trapping the sediment $25 \%$ more at low tide than at high tide. From these

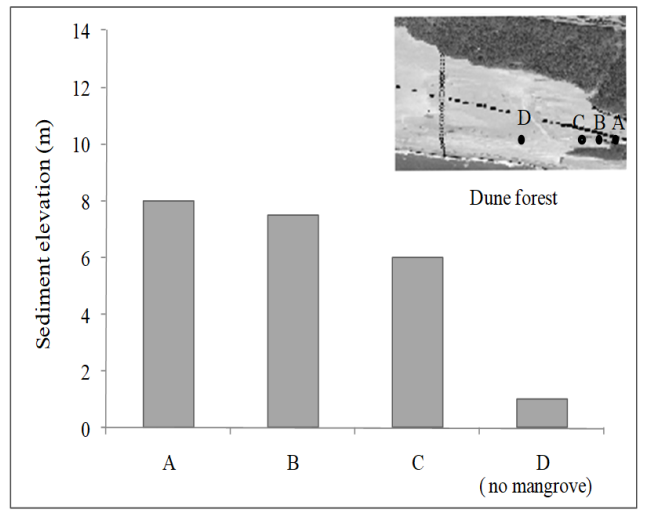

(a) two modes (estuarine mangrove and dune forests), it is clear that there is a similarity of sedimentation between mangrove forests and dune vegetation.

\section{Energy dissipation vs sedimentation}

An important ability of coastal forests is to trap sediments and to protect coastal areas during coastal floods due to storm surge or cyclone by stabilizing the shore. Forests are considered as an ideal sink of suspended sediments and as an alternative for coastal stabilizations, thus minimizing soil erosion and damage to properties along the coast. In Fig. 8, Furukawa et al. (1997) measured the sedimentation rate in the mangroves by trap method from the creek's edge whereas, present study shows the measurement of wave energy reduction in the forest. The field measurements by Furukawa et al. (1997) were undertaken over three successive spring tidal cycles on 2-4 December 1994, along a transect through the natural mangroves from the creek edge. Major mangrove species are Rhizophora sp., Bruguiera gymnorhiza and Ceriops tagal.

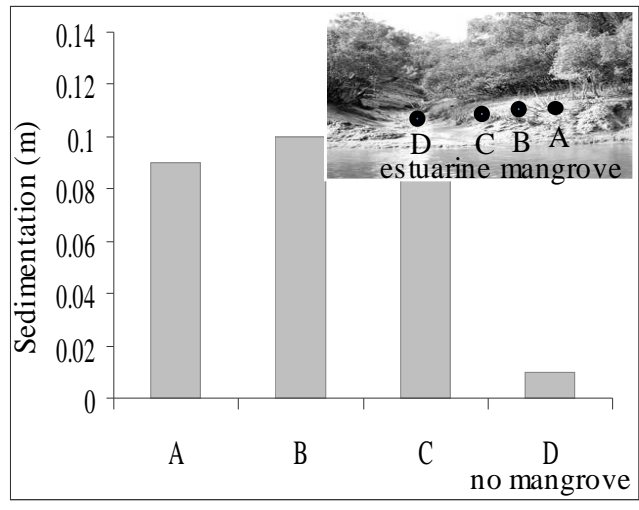

(b)

Fig. 7. Effect of forest vegetation on sedimentation: (a) sediment deposition in estuarine mangrove (Sundarban) and (b) sediment elevation in dune forest to mangrove-lined bank and non-mangrove bank. Legend: A-C mangrove-lined bank data and D non-mangrove bank data. 


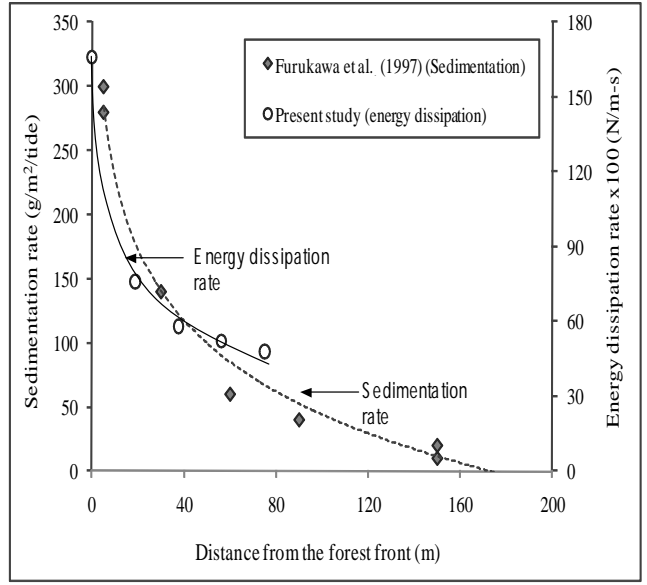

Fig. 8. Relationship between energy dissipation and sedimentation rate induced by forests. The mangrove sedimentation data are taken from Furukawa et al. (1997).

There are 30-40 trunks (including roots) per $\mathrm{m}^{2}$, with a mean diameter $4.0 \mathrm{~cm}$. The width of the mangrove forest through the mangrove wetland was about $200.0 \mathrm{~m}$. In the present experiment, different heights $(2.5-12.5 \mathrm{~cm})$ of staggered cylinder were used for wave attenuation where diameter of each cylinder was $0.6 \mathrm{~cm}$ and the distance between two consecutive cylinders was $1.09 \mathrm{~mm}$. Analysis of two independent estimations shows that there is a similarity between wave attenuation curve and sediment deposition curve (Fig. 8). This observation suggests that the soil particles settle in the forests during storm surge as the wave energy gets reduced by coastal forests. Although the comparison between two independent estimations are very rough, it can be said from practical observation that the storm and tide induced flow around the vegetation generates eddies and stagnation zones where the suspended sediment brought in at rising tide will settle; the tidal currents are too small at falling tide to re-suspend all that sediment; thus the vegetated tidal flat silts.

\section{CONCLUSIONS}

An analysis on sedimentation shows that there is a similarity between dune and beach forests within a mangrove-line bank (A, B, C) and without mangrove (D). From the Nakatajima dune, it is observed that the larger amount of sediment is transmitted in June and November, which may be due to higher wind speed. The average volume of migrated sediment was calculated about $442 \mathrm{~m}^{3} /$ year from study area in 2008. On the other hand, although water supply through the Padma has been reduced substantially (in the year 2008, 2009 and 2010 annual peak discharge were 54000, 40000 and $30000 \mathrm{~m}^{3} \mathrm{~s}^{-1}$ respctively), but siltation on the river-bed has increased significantly. After setup the $\mathrm{CC}$ blocks and groynes on the riverbank, the sedimentation rate was observed almost twice than that of the previous year. The achieved results though relative, might be important for the low-lying coastal areas where storm surges are more likely to occur such as Bangladesh.

\section{ACKNOWLEDGEMENT}

The first author would like to acknowledge the financial support provided by the Alexander von Humbolt Foundation (AvH) within the Georg Forster Experienced Research Programme and JASSO.

\section{REFERENCES}

Adame M. F., D Neil., S. F. Wright and Lovelock C. E. 2010. Sedimentation within and among mangrove forests along a gradient of geomorphological settings. Estuarine, Coastal and Shelf Science 86: $21-30$.

Alongi D. M. 2008. Mangrove forests: Resilience, protection from tsunamis, and responses to global climate change. Estuarine, Coastal and Shelf Science 76: 1-13. 
BWDB, 2008. Technical report of joint committee of BUET, IWM and BWDB on evaluating effectiveness of sand filled geobags using technology in riverbank erosion protection works (in Bangla). Bangladesh Water Development Board, Ministry of WaterResources, The Government of People's Republic of Bangladesh.

Carter R. W. G. 1991. Near-future sea level impacts on coastal dune landscapes. Landscape Ecology, pp. 29-39.

Cebrain J. 2002. Variability and control of carbon consumption, export, and accumulation in marine communities. Limnology and Oceanography 47: 11-22.

Clemett A., M. M. Amin, S Ara. and M. R. Akan 2006. Background information for Rajshahi City. WASPA Asia Project Report 2, pp. 28.

Cowell P. J., B. G. Thom, Jones, R. A., C. H. Everts and D Simanovic 2006. Management of uncertainty in predicting climate-change impacts on beaches. Journal of Coastal Research 22: 232-245.

Ellison J. C. 1993. Mangrove retreat with rising sea level, Bermuda. Estuarine, Coastal and Shelf Science 37: 75-87.

Farnsworth E. J., A. M. Ellison and W. K. Gong 1996. Elevated $\mathrm{CO}_{2}$ alters anatomy, physiology, growth, and reproduction of red mangrove (Rhizophora mangle L.). Oecologia 108(4): 599-609.

Fujimoto K. 2000. Belowground carbon sequestration of mangrove forests in the Asia-Pacific region. Proceedings of AsiaPacific Cooperation on Research for Conservation of Mangroves, Okinawa, Japan, pp. 87-96.
Furukawa K, E Wolanski, H Mueller 1997. Currents and sediment transport in mangrove forests. Estuarine, Coast and Shelf Sci. 44: 301-310

Harada K., F. Imamura and T. Hiraishi 2002. Experimental study on the effect in reducing tsunami by the coastal permeable structures. Final Proc. Int. Offshore Polar Eng. Conf., USA, pp. 652-658.

IPCC, 2007. Climate change: Fourth assessment report (Coastal systems and low-lying areas). pp. 317-357.

Katherisan K. 2003. How do mangrove forests induce sedimentation? International Journal of Tropical Biology and Conservation 51(2): 355-360.

Kathiresan K. and N. Rajendran 2005. Coastal mangrove forests mitigated tsunami. Estuarine coastal and Shelf Science 65: 601-606.

JSCE 2008. Investigation report on the storm surge disaster by cyclone SIDR in 2007, Bangladesh, 81, http://www.jsce.or.jp/report/46/files/Bangladesh_Inv estigation.pdf.

Junaidi and S. Aoki 2009. Wind-blown sand and topographic changes of the coastal dune at the eroded beach. Journal of Coastal Research (Special Issue) 56: 322-326.

Mukhopadhyay S. K., T. K Jana., T. K. De and S. Sen 2000. Measurement of exchange of $\mathrm{CO}_{2}$ in mangrove forest of Sundarbans using micrometeorological method, Tropical Ecology 41(1): 57-60.

NHC, 2006. Physical model study, Final report, Jamuna Meghna River Erosion Mitigation Project (JMREMP), Northwest Hydraulic Consultant, Vancouver-Canada, Bangladesh Water Development Board (BWDB), Ministry of Water Resources. 
Nicholls R. J., F.M.J. Hoozemans and M. Marchand 1999. Increasing flood risk and wetland losses due to global sea-level rise: regional and global analyses. Global Environmental Change 9: 69-87.

Parkinson R.W., R.D. DeLaune and J.C. White 1994. Holocene sea-level rise and the fate of mangrove forests within the wider Caribbean region. Journal of Coastal Research 10: 1077-1086.

Richmond B.M., B. Mieremet and T.E. Reiss 1997. Yap Islands natural coastal systems and vulnerability to potential accelerated sea-level rise. Journal of Coastal Research (Special Issue) 24: 153-173.

Saenger P. and N. A. Siddiqi 1993. Land from the sea: the mangrove afforestation program of Bangladesh. Ocean \& Coastal Management 20: 23-39.

Santen P. V., P.G.E.F. Augustinus, JanssenB.M. Stelder, S. Quartel and N.H. Tri 2007. Sedimentation in an estuarine mangrove system. Journal of Asian Earth Sciences 29: 566-575.

Snedaker S.C., J.F. Meeder, R.S. Ross and R.G. Ford 1994. Discussion of Ellison and Stoddart, 1991. Journal of Coastal Research 10: 497-498.

Taaouati M., A. E. Mrini and D. Nachite 2011. Beach Morphology and Sediment Budget Variability Based on High Quality Digital Elevation Models Derived from Field Data Sets. International Journal of Geosciences 2: 111-119.
Uddin MN, MA Rahman, M. Arifuzzaman, MA Sayem and SM. Ashraful Abedin Asha, 2016. Study of economic mineral in the Padma River sand and detection of bank erosional sites with its canses from chapainawabganj district to manth of the Gorairiver, Kustia district, Bangladesh.

Wahed M. D., M. S. Sadik and M. S. Muhit 2011. Environmental impacts of using sand filled geo-bag technology under water in river erosion protection of major rivers in Bangladesh. ICETCESD, Sylhet, Bangladesh.

Wolanski E. 1995. Transport of sediment in mangrove swamps. Hydrobiologia, 295: 31-42.

Wibisono I.T.W., S. Ichwan, M. Ilman and N. Suryadiputra 2011. Carbon assessment and anticipated carbon project in a degraded mangrove forests in Pasang Kayu area of the Mamuju Utara district, West Sulawesi province, Indonesia

Webster and C. D. Hoyos 2004. Extended-range probabilistic forecasts of Gangs and Bharmaputra floods in Bangladesh. (Internet).

World Bank, (2000) Bangladesh: climate change \& sustainable development. Report No. 21104 BD, Dhaka.

(Received revised manuscript on 13 March 2019) 